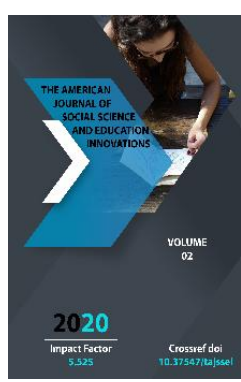

Copyright: Original content from this work may be used under the terms of the creative commons attributes 4.0 licence.

\section{Preparing Future Teachers To Solve The Tasks Of Patriotic Education Of Children And Youth}

\author{
Shirinboy Sharofovich Olimov \\ Professor Of Bukhara State University, Doctor Of Pedagogical Sciences, Uzbekistan \\ Khusniddin Kupayinovich Khomidov \\ PhD Student At The Bukhara Engineering And Technology Institute, Uzbekistan
}

\title{
ABSTRACT
}

In this article, the essence and significance of the solution of issues of patriotic upbringing of young people and children, their role in society, the development and implementation of projects on patriotic education of youth in educational institutions of the region (city, district), including vocational colleges As education and patriotic education are an urgent problem, research on effective pedagogical tools has been highlighted.

\section{KEYWORDS}

Patriotism, future teacher, youth and children, Homeland, loyalty, upbringing.

\section{INTRODUCTION}

Today in the era of economic and social transformation, the problem of patriotism is becoming more acute. Patriotism is the core of the spiritual and moral education of growing citizens, the most important resource of social energy aimed at reviving the country, its economy, culture, defense. Patriotism is a social feeling, the content of which is love for the motherland, devotion to it, pride in its past and present, the desire to protect its interests.
Patriotism is one of the most important values inherent in all spheres of human life, society and the state. Patriotism is the spiritual heritage of the individual, characterizes the highest level of its development and is manifested in active self-realization for the benefit of the Fatherland.

The studies of many scientists and the development of practitioners show that today 
the manifestation of patriotism can be identified by the manifestation of the following personal qualities: love of the big and small homeland, willingness to fulfill the constitutional duty, modern patriotic worldview, social tolerance, including religious and national, social meaningful behavior and activities. Patriotism appears in the unity of spirituality, morality, citizenship and social activity of the individual.

\section{MATERIAL AND METHODS}

Patriotism manifests itself already in childhood, develops and enriches in the social, spiritual and moral sphere of life. In connection with the lack of a sense of patriotism, young people exacerbate social problems such as the collapse of the system of social relations, the collapse of social structures, the ideological vacuum, dehumanization and criminalization of society.

In today's unstable conditions, patriotism as the most important quality of an individual can and should become the basis for the consolidation of society and the strengthening of the state. Patriotism is a matter of conscience for every citizen who loves the Motherland, his inner call and the need to participate in the decision of the fate of the Fatherland. As you can see, there is a need for comprehensive work on the patriotic education of children and youth.

The essence and content of patriotic education from a pedagogical point of view can be represented as a process of interaction between teachers and pupils, aimed at developing patriotic feelings, the formation of patriotic beliefs and stable norms of patriotic behavior. The activities of educational institutions should be aimed at educating a person who is a citizen, a patriot of the Motherland, at forming students 'and pupils' worldview and value orientations, thereby contributing to the expansion and enrichment of the system of relations to the small and large Motherland and the world around it.

\section{RESULTS AND DISCUSSION}

At the present stage of the development of education in the country, the school has an urgent need for a teacher who is able to educate patriots who are ready to defend their Fatherland, be devoted to their people and work for the good of their country and people. The valuable reorientation of society has led to the need to form a qualitatively new school and a new teacher. However, the system of vocational and pre-vocational education is not focused on solving the problems of educating patriotism as the moral position of a future teacher, capable of further fulfilling the mission of patriotic and moral education of students in modern conditions of humanization and humanization of education.

Analysis of scientific and methodological literature on the patriotic education of children and students (A.G. Agaev, AA Aronov, T.A. Belov, M.I. Bogomolova, I.N. Boldyrev, M.I. Valeev, Yu.S. Vasyutin, A.N. Vyrshchikov, Z.T. Gasanov, I.I. Gubanov, R.K. Huseynov, A.D. Zharikov, A.P. Kabatchenko, X.A. Kadiev, V.A. Karakovsky, A.E. Kondratenko, AC Milovidov, K.V. Nazarenko, G.M. Rogachev, M.N. Rosenko and others), allows us to formulate one of the insufficiently developed, but urgent problems the search for effective pedagogical means of patriotic education.

Based on the idea that the formation of a person's personality takes place in the three most important areas of life - consciousness, relationships and activities (A.N. Leontyev), we believe that patriotism, first of all, should be manifested in patriotic actions, social activity of the person. The patriotic education of college students should be aimed at the formation of patriotic consciousness, the foundations of legal, political culture, knowledge of history and traditions of their region; the development of patriotic feelings 
and relations (citizenship, a sense of social responsibility, duty, pride in one's homeland); accumulation of experience and culture of patriotic behavior of ideology. We focus our pedagogical search on the development of means of an activity-mediated (V.I. Lutovinov) approach to the organization of patriotic education of students of pedagogical college.

In pedagogy, the issue of effective means of patriotic education, focused on all three components of this process, is actively discussed. One of such means, in a college setting, is the inclusion of future professionals in professional and volunteer activities aimed at the patriotic education of children and youth.

The effectiveness of educational work is ensured by the direct participation of students in the development and implementation of innovative organizational forms and methods of patriotic education of students. At the same time, we consider it important that future specialists show conscious activity at all stages of pedagogical activity (from goal-setting and design to testing and pedagogical analysis).

The analysis of the process of specialist training in the institution of secondary specialized vocational education in the conditions of the city (district center) revealed the following problems that need to be solved in the process of development and implementation of the project:

- The problem of patriotic education of college students;

- The problem of training future specialists to solve the problems of patriotic education of various population groups in the upcoming professional activity;

- The problem of the development of the college's social partnership with the aim of combining the efforts of educational, spiritual and social organizations and institutions of the city and the municipal district to solve the problem of patriotic education of children and learning youth;

- The problem of developing the innovative potential of the college teaching staff;

- The problem of developing the image of the college as a center of cultural and educational activity of a city (district);

- The problem of attracting students.

The listed problems can be successfully comprehensively solved in the process of the implementation by teachers and college students of the search and development of effective means of patriotic education, focused on the formation of patriotic awareness, the foundations of legal, political culture, knowledge of history and traditions of their region; the development of patriotic feelings and relations (citizenship, a sense of social responsibility, duty, pride in one's homeland); accumulation of experience and culture of patriotic behavior and activity.

Currently, work is underway at the teacher training college to create an innovation program on the topic "College - the center of patriotic education of children and youth of a city (district)".

Project goals: development of the components and characteristics of the educational process in a pedagogical college, ensuring the formation of patriotic consciousness among students, the foundations of legal, political culture, knowledge of history and traditions of their region; the development of patriotic feelings and relations (citizenship, a sense of social responsibility, duty, pride in one's homeland); accumulation of experience and culture of patriotic behavior and activity; the formation of competencies among teachers related to solving the problems of patriotic education of students in the process of organizing educational, extracurricular activities, students' leisure time, as well as during practical training; the formation of future specialists' readiness to solve the problems of patriotic education of various 
population groups in the upcoming professional activity.

Project Objectives:

1. The definition and characteristics of indicators and criteria for the manifestation of the formation of students' patriotic consciousness, attitude, activity; readiness to solve the tasks of patriotic education of various population groups in professional activities.

2. The development of the college's social partnership with the aim of combining the efforts of educational, spiritual and social organizations and institutions of the city and the municipal district to solve the problem of patriotic education of children and learning youth.

3. The creation of a diagnostic bank to identify the level of patriotic education of college students and determine the willingness of future specialists to solve the problems of patriotic education of various population groups in professional activities.

4. Determination of the main areas of patriotic education carried out in college as the center of patriotic education of children and youth of a city (district), development of the content and practical and practical support for these areas of activity of the teaching staff.

5. The introduction of the developed pedagogical means of patriotic education of children and students in the educational practice of the college and interaction with other educational, spiritual and social organizations and institutions of the city (district) to solve the problem of patriotic education of children and students.

6. The formation of students' patriotic consciousness, attitude, activity; readiness to solve the tasks of patriotic education of various population groups in professional activities.

7. Organization of a system of methodological measures (individual, group, collective) to improve the professional and pedagogical competence of teachers and their readiness to implement the main directions and develop, and introduce pedagogical means of patriotic education of college students, children and students of other educational organizations of the city (district).

\section{CONCLUSIONS}

Work on this program will allow the teaching staff of the college to contribute to the implementation of such priority areas for the development of the education system as: improving the quality of training of mid-level specialists for institutions and organizations based on the requirements of employers and consumers of professional services; ensuring the professional education of future specialists, contributing to the establishment of moral ideals and values in society; increasing the innovative potential of the system of secondary specialized vocational education by introducing into the educational process technologies of patriotic education of future specialists; development of methodological products that allow teachers of institutions of secondary specialized vocational education in the region to solve the problems of patriotic education of students and the formation of future specialists' willingness to solve the problems of patriotic education of various population groups in professional activities.

\section{REFERENCES}

1. Abdullina, O.A. General pedagogical teacher training in the system of higher pedagogical education [Text] / OA Abdullina. - M :: Education, 2010 .- 346 p.

2. Ippolitov, N.V. Theory and practice of preparing future teachers for patriotic education of students [Text] / N.V. Ippolitov: the dissertation of the doctor of pedagogy / N.V. Ippolitova - Chelyabinsk, $2000 .-383$ p. 
3. Olimov S.Sh. Pedagogy (text of the lecture). - Bukhara, 2016

4. Shamsitdinova, M. G. (2020). INTERCULTURAL COMMUNICATION AND PROBLEMS OF TEACHING ENGLISH TO THE STUDENTS-NONLINGUISTS. Theoretical \& Applied Science, (4), 1024-1026.

5. Shamsitdinova M. THE IMPACT OF INFORMATION TECHNOLOGIES ON DISTANCE EDUCATION DURING PANDEMIC IN THE REPUBLIC OF UZBEKISTAN. PalArch's Journal of Archaeology of Egypt / Egyptology. ISSN: 1567-214X, Netherlands, pp. 8962-8967

6. Boltabayevich, B. B., \& Shodievna, B. O. (2020). Individual Approach To The Formation Of Artistic And Creative Talents Of Students In Art Schools. The American Journal of Social Science and Education Innovations, 2(08), 637-642.

7. Boltaboevich, B. B. (2020). Formation of the skills of portraying the future teacher of fine arts in pencil drawing. ACADEMICIA: An International Multidisciplinary Research Journal, 10(5), 1122-1127.

8. Baymetov, B. B., \& Sharipjonov, M. S. O. (2020). Development Of Students' Descriptive Competencies In Pencil Drawing Practice. The American Journal of Social Science and Education Innovations, 2(08), 261-267.

9. Salakhova Z., M.Shamsitdinova. ADVANCED PEDOGOGICAL TECHNOLOGIES IN EDUCATION IN THE 21-ST CENTURY. International Scientific Journal Theoretical \& Applied Science, USA, pp. 743-746. 